\title{
CARVALHO, Luciana Beatriz de Oliveira Bar de \& CARVALHO, Carlos Henriques de (2012). O lugar da Educação na Modernidade luso-brasileira no final do século XIX e início do século $X X$. Campinas, SP: Editora Alínea
}

O desafio que nos é colocado no presente livro prende-se com o repensar a história da educação numa dimensão comparativa. Estamos face a uma perspetiva distinta de compreender a construção do Estado moderno em dois países que partilharam uma história que se entrecruzou durante anos: Brasil e Portugal. Certamente as realidades socio-históricas revelem particularidades intrínsecas à forma como se processou a negociação com o mundo social para se implementar e executar a criação de uma organização da sociedade em moldes que compaginassem as emergentes dinâmicas de matriz moderna. Sublinham os autores, com pertinência, que estudar as reconfigurações locais é essencial para se poder entender a modernidade na sua amplitude simbólica e social. Enfatizam, também, que se deve ultrapassar o estatuto marginal que o nível micro tem no contexto dos sistemas políticos nascentes e salientam, ainda, que é crucial analisar a competição plural entre projetos políticos rivais - ora oriundos de uma mesma linhagem ideológica republicana, ora manifestando fundamentos declinados na múltipla significação do liberalismo -, balizando que os discursos relevam estratégias nítidas de organizar o território e os atores, instituindo tópicos mobilizadores para um futuro singular.

O dínamo desse projeto foi a educação, estruturada (lá como cá) como o lugar da emergência da consciência moderna. É justamente neste ponto que é concebido o comparável entre as duas sociedades - ilustrado empiricamente pelo modo como a educação pública foi concebida, implementada e disseminada em dois municípios: no Brasil, Uberaninha (Minas Gerais), e em Portugal, Mafra. O período da primeira República é o tempo comum às duas realidades geográficas (sabendo-se que a implementação do novo regime não teve a mesma cronologia mas a historiografia de ambos os países tem evidenciado os ritmos idênticos na sua consolidação social, e inclusive identificado homologias na sua contestação) e a unidade administrativa é similar: o município. No entanto, deve-se ter em atenção a especificidade jurídico-territorial que tal designação adquire nos dois contextos, preocupação essa que os autores sinalizam com frequência 
ao longo do texto, recordando que, para além da óbvia extensão territorial, o que deve ser compreendido é o modo como no espaço se refletem as posições políticas, nomeadamente através do balanceamento entre centralização e descentralização, ou seja, a maior ou menor autonomia que estas unidades territoriais vão tendo.

O conceito de município pedagógico - trabalhado a partir da reflexão pioneira de Justino Magalhães - é substantivado através das dimensões que o estruturam em estreita relação com a identificação das fontes e de muitos outros índices que uma investigação desta natureza exige. O inventário da informação é essencial porque sinaliza os protagonistas do fenómeno, à escala local, desvendando as centralidades da produção discursiva pela natureza da experiência política e institucional, ora rastreando o peso das elites - na sua variedade sociossemântica -, ora as interpelações dos agentes sociais situados nas periferias do sistema. É este relato minucioso de construção conceptual do objeto que os autores nos restituem ao possibilitar pensar uma "nova geografia" (na desafiante expressão de João Barroso) da lusofonia (em torno desta categoria, o diálogo estabelecido com historiadores portugueses é intenso, pertinente e profícuo), na sua singularidade comparativa, ou seja, o único e o diferente.

Entre os méritos que o estudo patenteia, cumpre pontualizar, em primeiro lugar, a reflexão epistemológica sobre a história comparada - que prolonga um debate iniciado por Wenceslau Gonçalves Neto e Carlos Henriques de Carvalho, "Tendências e perspetivas em História Comparada no campo da Educação", Cadernos de História da Educação, 4 (2005), pp. 183190 (et passim), mas que desde, pelo menos, 2001 vem acontecendo na comunidade de historiadores da educação brasileiros - que se embebe numa discussão mais ampla (bastante presente na História da Educação dos dois países) sobre as potencialidades heurísticas da dimensão local. As pistas que o livro patenteia são seguramente uma via para se irem aprofundando os estudos desta natureza, porque a "educação como fenómeno histórico é passível de ser investigada à luz da própria história" (p. 23). Em segundo lugar, interessa explorar o conceito de modernidade nas antropologias das sociedades brasileira e portuguesa, na transição do século XIX, por um lado, caracterizando, e cartografando, os elementos estruturantes (urbanismo, higienismo, controle das populações, ..., projetos políticos) de um novo regime de historicidade - a modernidade - com os seus ritmos diferenciados e as suas a-sincronias, em sociedades desiguais, como ainda, por outro lado, 
identificando as modalidades de imposição de um novo espaço-tempo (real e simbólico) e as peculiares prosopografias da sociologia do fenómeno. Uberabinha e Mafra são estudadas à luz desta transformação, inserindo-se o denominador comum - implementação da escola pública - num duplo ângulo: circulação do pensamento e práticas democráticas, sintetizado pelos autores do seguinte modo: "Se por um lado, proclamava [a República] a educação como direito individual a ser assegurado a todos, por outro, não se preocupou com a sistematização desse direito" (p. 50).

Uma atenção muito particular é colocada na correlação entre modernidade social, modernidade económica e modernidade do projeto republicano, destacando-se as resistências, os desencontros, as diferentes posições legitimadoras, a formação de grupos sociais heterogéneos e o acentuar das distâncias entre o centro (as elites, nas suas diversas hegemonias) e as periferias (classes populares, rurais, operários). Estas tensões são justamente a declinação do específico em cada um destes laboratórios sociais, que indelevelmente marcam dimensões imprescindíveis para a construção do município como objeto histórico, ou, como sublinham os autores, "a cidadania embasou a sociabilidade educativa" (p. 193).

Um último aspeto a realçar é de ordem metodológica, que se traduz no estímulo que à História da Educação a história comparada significa, não bastando, por isso, compartilhar conceções teóricas: importa sobretudo ir construindo "instrumentos comuns de pesquisa, tratamento de fontes e criação de categorias úteis" (p. 23), e só traçando este caminho é que as diferenças, "se forem realizadas transversalmente, ou seja, com base em imbricações, particularidades, nexos e contradições" (p. 193), poderão ser detetadas. Neste aspeto o estudo mostra-se interessante, propondo a reconstrução de um outro trajeto de centrar a educação na temporalidade política da modernidade, na sua significação e na sua apropriação, mas também na sua especificidade social enquanto qualificação positiva da democracia, promessa de bem- estar coletivo e dignificação da gente comum. E esta é também uma história comum ao Brasil e a Portugal, que o presente livro ensaia com mérito.

José António Afonso

Centro de Investigação em Educação (CIEd), Universidade do Minho 